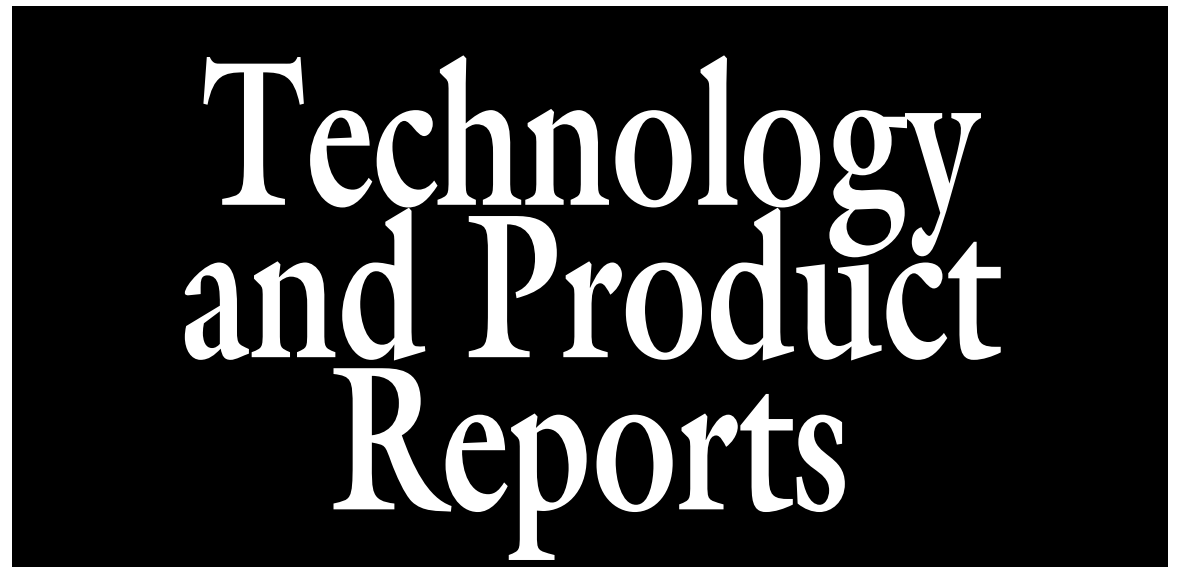

\section{Mulching with Large Round Bales between Plastic-covered Beds Using a Newly Developed Offset Round-bale Unroller for Weed Control}

\author{
John Wilhoit ${ }^{1,3}$ and Timothy Coolong ${ }^{2}$
}

\section{ADDITIONAL INDEX WORDS. organic, mulch, round bales, watermelon}

SUMMARY. Mulching between rows of plastic used for vegetable production can be an effective practice for controlling weeds. An existing round-bale unroller was modified to create an offset bale unroller, allowing round bales of hay to be unrolled between planting rows with a tractor. This modification has made the practice of mulching with round bales of hay or wheat straw more efficient. This offset round-bale unroller was used to apply hay and wheat straw mulch to between-row areas of 'Crimson Sweet' watermelon (Citrullus lanatus) in 2009 and 2010. Hay and wheat (Triticum sp.) straw mulches were applied at two thicknesses, corresponding one and two layers of mulch from the round bale, respectively. All of the hay and wheat straw mulch treatments controlled weeds significantly better than the non-treated controls in both years. There was a significant mulch-type by year interaction for weed control, with 1-year-old hay having less weed control in 2010 compared with 2009, whereas other mulches had improved weed control in 2010. One-year-old wheat straw and new hay had the lowest levels of weed biomass present compared with new wheat straw and the no-mulch control. Mulch thickness significantly affected weed control, with mulches applied in two layers having significantly less weed biomass than those applied in one layer. Weed pressure was significantly less in 2010 compared with 2009. The offset bail-unroller that has been developed to apply mulches to between-row areas of plastic-covered beds is a useful tool that can be used to efficiently unroll round bales of a variety of organic mulches for weed control.

$\mathrm{T}$ he practice of applying mulches for the production of vegetables dates back thousands of years (Coolong, 2012; Rowe-Dutton, 1957). A primary purpose for using mulches is for weed suppression in the crop to be grown. Mulches typically function by blocking light or creating environmental conditions

${ }^{1}$ Department of Biosystems and Agricultural Engineering, 208 C.E. Barnhart Building, University of Kentucky, Lexington, KY 40546

${ }^{2}$ Department of Horticulture, N-318 Ag. Science North, University of Kentucky, Lexington, KY 40546

${ }^{3}$ Corresponding author. E-mail: jwilhoit@bae.uky.edu. that can prevent germination or suppress weed growth shortly after germination. However, numerous other benefits are often obtained including increased earliness, moisture conservation, temperature regulation of the root zone and aboveground growing environment, reduced nutrient leaching, altered insect and disease pressures, and in some instances, reduced soil compaction or improved soil organic matter (DiazPerez, 2010; Lamont, 1993, 2005; Ngouajio and McGiffen, 2004). Currently, polyethylene (plastic) filmmulches are the primary mulch used in vegetable production for in-row weed control; however, weed control between rows can be a significant challenge for some producers. Weeds can hinder access for crop maintenance and harvesting activities affecting yields (Law et al., 2006). Weed control is especially challenging for organic growers. In a national survey of organic growers, weed control was ranked as their number one research priority (Walz, 1999).

Using hay and wheat straw mulches between rows of plastic is a chemical-free weed control option that adds organic matter to the soil and can control weeds on the edges of plastic mulch beds where control by other methods may be difficult. Organic mulches between rows can also reduce soil splash during rains (Stall, 2008). The weed control effectiveness may also be dependent on the quantity of mulch used. Schonbeck (1996) considered 7 to 10 tons/acre of hay or wheat straw to be sufficient for weed control, while 4 to 5 tons/ acre were not. However, rye (Secale cereale)-based mulches applied at a rate of 2.3 tons/acre were adequate for controlling weeds in summergrown cabbage (Brassica oleracea var. capitata) in Poland, suggesting that local environmental factors will likely have an impact on the effectiveness of varying rates of organic mulches (Zaniewicz-Bajkowska, 2009).

\begin{tabular}{llll}
\hline $\begin{array}{l}\text { Units } \\
\text { To convert U.S. to SI, } \\
\text { multiply by }\end{array}$ & U.S. unit & SI unit & $\begin{array}{l}\text { To convert SI to U.S., } \\
\text { multiply by }\end{array}$ \\
\hline 0.3048 & $\mathrm{ft}$ & $\mathrm{m}$ & 3.2808 \\
0.0929 & $\mathrm{ft}^{2}$ & $\mathrm{~m}^{2}$ & 10.7639 \\
3.7854 & gal & $\mathrm{L}$ & 0.2642 \\
0.7457 & horsepower & $\mathrm{kW}$ & 1.3410 \\
2.54 & inch $(\mathrm{es})$ & $\mathrm{cm}$ & 0.3937 \\
1.1209 & lb/acre & $\mathrm{kg} \cdot \mathrm{ha}^{-1}$ & 0.8922 \\
28.3495 & $\mathrm{oz}$ & $\mathrm{g}$ & 0.0353 \\
1 & $\mathrm{ppm}$ & $\mathrm{mg} \cdot \mathrm{L}^{-1}$ & 1 \\
2.2417 & ton/acre & $\mathrm{Mg} \cdot \mathrm{ha}^{-1}$ & 0.4461 \\
$\left({ }^{\circ} \mathrm{F}-32\right) \div 1.8$ & ${ }^{\circ} \mathrm{F}$ & ${ }^{\circ} \mathrm{C}$ & $\left({ }^{\circ} \mathrm{C} \times 1.8\right)+32$ \\
& & &
\end{tabular}

Hortlechnology · August 2013 23(4) 
Incorporating cultivation along with mulching can be important for achieving effective weed control. Law et al. (2006) reported that when organic mulches were applied early in the growing season without any prior mechanical cultivation, weed control was inadequate, resulting in low crop productivity. However, when mulches were applied after shallow cultivation of plots, adequate weed control was obtained throughout the harvesting season. According to Schonbeck (1996), many growers cultivate for several weeks after planting, and then apply mulches for effective weed control for the remaining part of the season.

Although hay and wheat straw mulches have many benefits, growers should be aware that mulch quality can also impact weed control effectiveness and introducing weed seeds can be a concern with organic-based hay and wheat straw mulches (Relf and McDaniel, 2004; Stall, 2008). Organic mulches tend to be more expensive in terms of materials and high application costs, especially for large-scale operations (Schonbeck, 2009). An alternative to the use of new hay or wheat straw for mulching that can cut costs substantially is to use old or spoiled hay that is no longer good for animal feed (Stout, 2011). Using round bales for mulching can also reduce the labor requirements considerably because there is more hay in each bale than in square bales. It is also notable that round bales can be handled mechanically and unrolled to peel off layers that are appropriate for mulching between rows of plastic. Tractor three-pointhitch-mounted bale unrollers that clamp on the center axis of round bales are used to lift and move large bales around and unroll them for feeding livestock. These implements carry the bale on the centerline of the tractor, so they cannot be used to unroll bales between rows of plastic because there is typically not enough space to drive the tractor between the rows. The objective of this study was to document the effects of modifying a traditional bale unroller such that the unroller could be offset a sufficient distance for the tractor to straddle the row of plastic and unroll the bale in the space between adjacent rows of plastic as well as test the efficacy of the modified unroller with

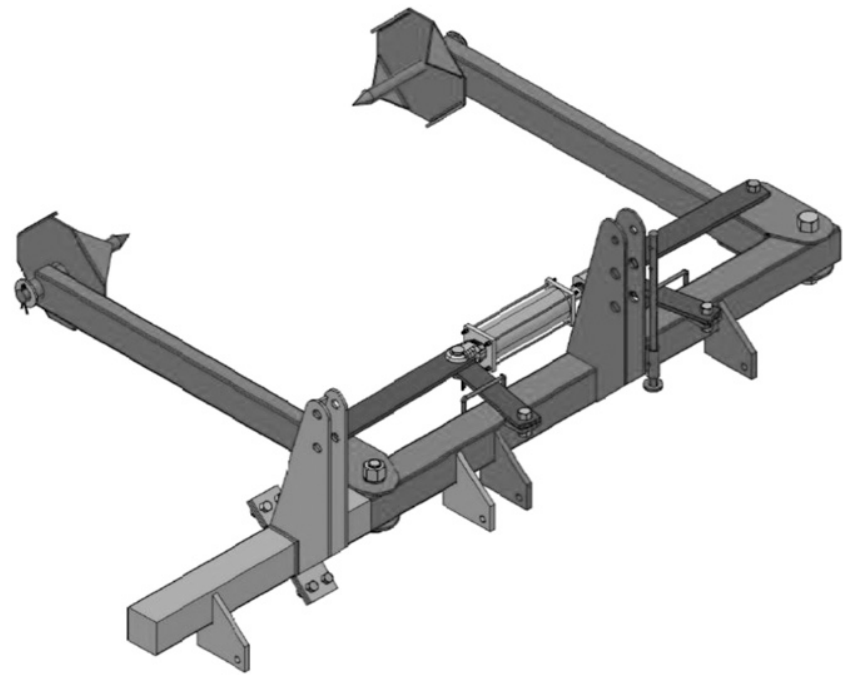

Fig. 1. Illustration of modifications made to a conventional round-bale unroller to make it offset, with the original implement shown dark and the added parts shown in lighter shade.

several types of organic mulches for between-row weed control.

\section{Materials and methods}

BALE UNROLLER MODIFICATIONS. The modifications to the bale unroller can be made to any conventional bale unroller provided that the clamping arms are open at the end where they pivot on the toolbar, allowing the additional length of toolbar to be welded on. A three-dimensional graphic of the offset bale unroller (Fig. 1) illustrates the modifications that were made, with the original bale unroller (model HHU-2045; Worksaver, Litchfield, IL) shown shaded dark and the parts added to make it offset shown in a lighter shade. As shown in an overhead view (Fig. 2), the toolbar was extended 27 inches and a new mast and lower hitch points were attached to the toolbar so that the bale was offset $\approx 36$ inches from the center of the row the tractor straddles. This offset distance makes the bale unroller appropriate for mulching with 4 -ft-wide round bales between plastic rows on typical bed spacing. An offset bale unroller made to these specifications can be used with tractors with either Category I or II three-point hitches. Note that the offset bale unroller is not intended for use with larger 5 - $\mathrm{ft}$-wide round bales, which would be considerably heavier and could cause the tractor be unstable when handling the bales. Design details for the lower hitch flange, mast assembly, and toolbar clamp are available (University of Kentucky, 2012).

An important feature of the offset bale unroller was the addition of a hydraulic top link (Fig. 2). By increasing in length to pivot the clamping arms downward, the hydraulic top link allows the offset bale unroller to be used for rolling bales out to a much smaller diameter than can be achieved with a fixed-length top link. Preliminary evaluations of rolling out smalldiameter bales with a fixed-length top link resulted in the tool bar being too low such that it can damage plants or the plastic covering the bed.

Costs for an offset bale unroller will vary depending on the cost of the bale unroller that is modified and the charges for metal fabrication. One was recently fabricated according to the plans for a total cost of $\$ 2070$ that included $\$ 1300$ for the unroller, $\$ 300$ for a hydraulic top link, and $\$ 470$ for the offset modifications (Plaskin, 2013).

Field trials. The offset bale unroller was used to roll out large bales of hay and wheat straw between the rows of plastic in watermelon plots in 2009 and 2010 at the University of Kentucky Horticulture Research Farm in Lexington, KY (lat. $38^{\circ} 3^{\prime} \mathrm{N}$, long. $84^{\circ} 30^{\prime} \mathrm{W}$ ).

Seed of 'Crimson Sweet' watermelon (Seedway, Elizabethtown, PA) were seeded into 128-cell plant trays filled with soilless media (Pro-Mix BX; Premier Tech, Riviere-du-Loup, QC, Canada) during the last 2 weeks of 


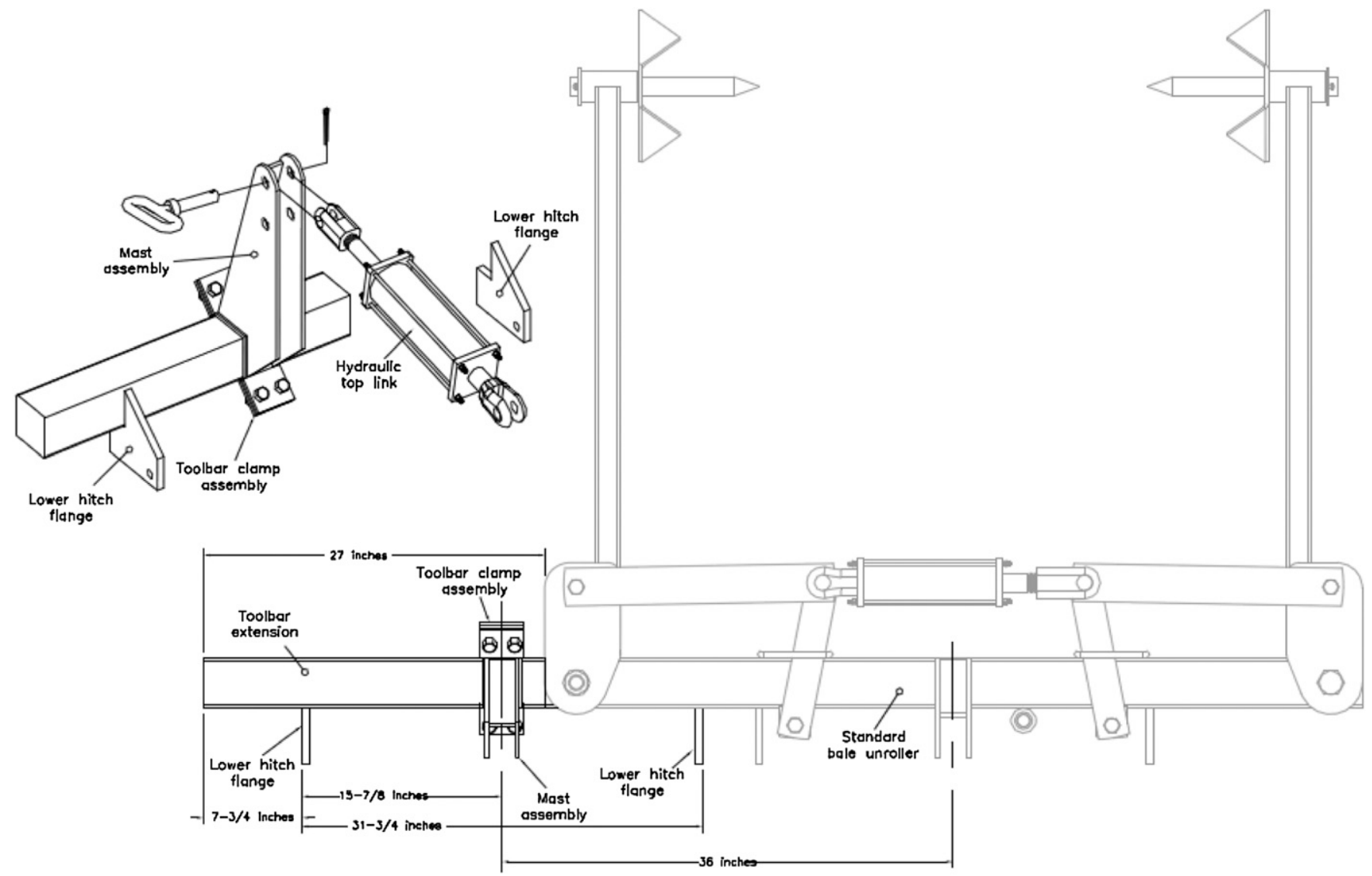

Fig. 2. Overhead view of offset bale unroller showing parts placement for assembly and extension and offset distances.

The three-dimensional inset shows the hydraulic top link that is lengthened to pivot the clamping arms downward as the round bale gets smaller $(1$ inch $=2.54 \mathrm{~cm})$.

May 2009 and 2010. Seedlings were greenhouse grown with temperature set points of $25 / 20{ }^{\circ} \mathrm{C}$ (day/night). Plants were watered daily as needed and fertilized weekly with a $150 \mathrm{mg} \cdot \mathrm{L}^{-1}$ nitrogen $(\mathrm{N})$ solution $(20 \mathrm{~N}-4.4 \mathrm{P}-$ 16.6K; Scotts, Marysville, OH). Plants were set into 4 - to 5 -inch-tall raised beds spaced on 8 - $\mathrm{ft}$ centers in 2009 and 7 - $\mathrm{ft}$ centers in 2010. Beds were covered with 1-mil embossed plastic mulch with a single line of drip irrigation tubing (12-inch emitter spacing, $0.45 \mathrm{gal} / \mathrm{min}$ per $100 \mathrm{ft}$, Aqua-Traxx; Toro, El Cajon, CA) placed $\approx 1$ inch below the soil surface in the center of each bed. The plastic mulch was 48 inches wide, and the formed beds were $\approx 32$ inches across the top. Transplants were placed in single rows on each bed with $\approx 3$-ft within-row spacing on 6 July 2009 and 21 June 2010. Preplant fertility (19N-8.3P15.8K; Southern States Cooperative, Richmond, VA) was applied under the plastic mulch at a rate of $75 \mathrm{lb} /$ acre $\mathrm{N}$. Plants were grown according to University of Kentucky recommendations for fresh market watermelon (Coolong et al., 2011).

In 2009 and 2010, the bare ground between the rows of plastic was cultivated on 16 July and 9 July, respectively. Round bales of hay and wheat straw mulch treatments were applied on 20 July 2009 and 12-14 July 2010, within 4 to $5 \mathrm{~d}$ of cultivation. In 2009, three hay or wheat straw mulches were used including new wheat straw, new mixed-grass hay, and 1-year-old mixed-grass hay. The new and 1 -year-old hay bales came from the same field and both were first cuttings. In 2010, an additional treatment, 1-year-old wheat straw, was added to the trial. The mulches were applied in two thicknesses, rolling the bales out in one layer $(\approx 4$ inches thick) and in two layers $(\approx 8$ inches thick). Experimental plots were $35-\mathrm{ft}$ long and the trial was a randomized complete block design with four blocks of seven (two thicknesses $\times$ three mulch treatments and control) and eight (two thicknesses $\times$ four mulch treatments and control) treatments in 2009 and 2010 , respectively.

Mulch biomass amounts were measured within $3 \mathrm{~d}$ after application in 2009 and 2010 by collecting all of the mulch between two boards spaced $3 \mathrm{ft}$ apart lain between the edges of the plastic and weighing the mulch in the field. The distance between the edges of the plastic was measured at each location and used to calculate the area that the mulch was sampled from. Weed biomass was determined on 30 Sept. 2009 and 7 Oct. 2010 by collecting all aboveground weed material from within two $8-\mathrm{ft}^{2}$ rectangular frames placed within the plots. The weed biomass was then oven-dried at $75^{\circ} \mathrm{C}$ for $24 \mathrm{~h}$ until a constant mass was achieved and weighed. Watermelons were harvested throughout September, although yield data were not collected for this trial.

Weed biomass data were analyzed using analysis of variance (PROC GLM) and mean separation using Duncan's multiple range test 
$(P<0.05)$ with SAS (version 9.1; SAS Institute, Cary, NC). The extreme Studentized deviate (Grubbs procedure) was performed on the data and when outliers were detected, if appropriate, they were removed. ANOVA included mulch-type by thickness by year and their interactions as sources of variance.

\section{Results and discussion}

Performance of the offset BALE UNROLLER. The offset bale unroller can be used with tractors with either a Category I or II threepoint hitch system but, in general, a minimum 35-horsepower tractor should be used with the implement. The offset bale unroller performed well with all mulch types in 2009 and 2010 (Fig. 3). The labor required to manually push mulch bales through fields was eliminated, reducing the

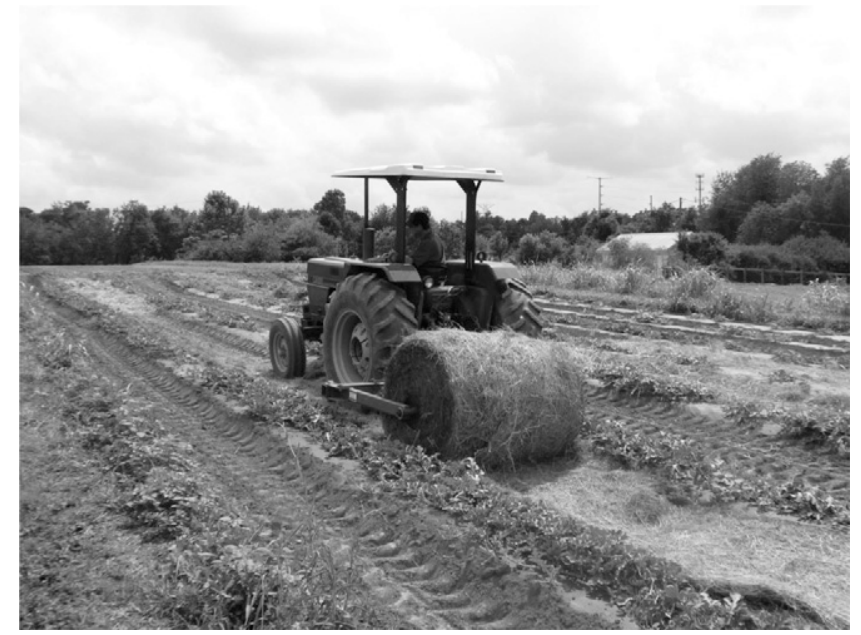

Fig. 3. Offset round-bale bale unroller unrolling a round bale of hay between plastic-covered beds in watermelon plots.

Table 1. Weight of hay and wheat straw mulches used between rows of plastic in 2009 and 2010 in Lexington, KY. Values are the means of four replications.

\begin{tabular}{lccc}
\hline & & \multicolumn{2}{c}{ Mulch wt $^{\mathbf{x}}$} \\
\cline { 3 - 4 } Mulch type $^{\mathrm{z}}$ & & $\mathbf{2 0 0 9}$ & $\mathbf{2 0 1 0}$ \\
\cline { 3 - 4 } Control (no mulch) & Thickness $^{\mathrm{y}}$ & - & lb/acre \\
New hay & - & 19,600 & - \\
New hay & $2 \mathrm{x}$ & 32,400 & 79,200 \\
l-year-old hay & $1 \mathrm{x}$ & 18,700 & 21,600 \\
l-year-old hay & $2 \mathrm{x}$ & 33,600 & 67,000 \\
New wheat straw & $1 \mathrm{x}$ & 16,600 & 18,000 \\
New wheat straw & $2 \mathrm{x}$ & 25,400 & 24,400 \\
l-year-old wheat straw & $1 \mathrm{x}$ & - & 29,600 \\
l-year-old wheat straw & $2 \mathrm{x}$ & - & 68,400 \\
\hline
\end{tabular}

${ }^{2}$ New mulches refer to hay or wheat straw harvest in the same year as the trial, while l-year-old mulches refer to those harvested 1 year before the trial year.

yThickness indicates mulch rolled out between rows in one layer $(1 \mathrm{x})$ or two layers $(2 \mathrm{x})$.

${ }^{x}$ Mulch weighed in the field, without any drying of the mulch; $1 \mathrm{lb} / \mathrm{acre}=1.1209 \mathrm{~kg} \cdot \mathrm{ha}^{-1}$ 1-year-old hay bales had areas of degradation where the bales had been stored on the ground that made the layers discontinuous until the bale had been rolled out sufficiently to get beyond the depth of the degraded area. Round bales of new wheat straw were the most difficult to mulch with as the freshly baled wheat straw was not much matted in layers. These bales required a considerable amount of manual spreading to achieve mulch thicknesses consistent with the other treatments. Interestingly, in 2010, round bales of 1 -year-old wheat straw could be rolled out uniformly in similar manner to the hay, whereas the new wheat straw was not. This experience suggested that the 1-year period for which the wheat straw was stored resulted in the wheat straw becoming more compressed and matted, allowing for a more uniform application.

Mulch biomasses were similar between new and 1-year-old hay in 2009 , for both applied thicknesses (Table 1). The mulch biomass amounts for the new wheat straw were less than that of the hay in both 2009 and 2010, indicating that the wheat straw was less dense and possibly dryer than the hay. However, the mulch amounts for the 1-year-old wheat straw, used in 2010, were considerably greater than new wheat straw at both thicknesses. This suggests that the 1-year storage time may have resulted in decomposition of the wheat straw mulch within the bale and possibly increased moisture in the wheat straw mulch. In contrast, the similar mulch biomass amounts between old and new hay in 2009, and the fact that the mulch biomass amounts for the 1-year-old hay were actually less than that of the new hay in 2010 at both thicknesses, indicate that the hay did not become more dense during the 1 -year storage period, possibly because the baled hay shed water better than the wheat straw.

Mulch biomass amounts were, in general, greater in 2010 than in 2009 at both thicknesses. Also, the two-layer thickness amounts were, in some cases, more than twice the amount of the single layer thickness in 2010. Rain in the afternoon on the mulches that were applied in 2010 likely contributed to higher weights (mulch biomass amounts were determined only as a control on the thickness 
Table 2. Dry weight of aboveground biomass for weeds per $16-\mathrm{ft}^{2}\left(1.5 \mathrm{~m}^{2}\right)$ plot of hay and wheat straw mulches used between rows of plastic in 2009 and 2010 in Lexington, KY. Values are the means of four replications.

\begin{tabular}{|c|c|c|c|c|c|}
\hline \multirow[b]{3}{*}{ Mulch type } & \multirow[b]{3}{*}{ Thickness $^{\mathrm{y}}$} & \multicolumn{4}{|c|}{ Weed wt } \\
\hline & & \multicolumn{2}{|c|}{2009} & \multicolumn{2}{|c|}{2010} \\
\hline & & \multicolumn{4}{|c|}{ Dry wt $(g)^{x}$} \\
\hline Control (no mulch) & - & 533.0 & $a^{w}$ & 100.0 & $\mathrm{a}$ \\
\hline New hay & $\operatorname{lx}$ & 20.0 & $\mathrm{~b}$ & 0.1 & $\mathrm{~d}$ \\
\hline New hay & $2 x$ & 3.6 & $\mathrm{~b}$ & 0.1 & $\mathrm{~d}$ \\
\hline 1-year-old hay & $\operatorname{lx}$ & 5.8 & $\mathrm{~b}$ & 76.5 & $\mathrm{ab}$ \\
\hline 1-year-old hay & $2 \mathrm{x}$ & 4.4 & $\mathrm{~b}$ & 0.1 & $\mathrm{~d}$ \\
\hline New wheat straw & $1 x$ & 64.0 & $\mathrm{~b}$ & 46.7 & bc \\
\hline New wheat straw & $2 \mathrm{x}$ & 24.3 & $\mathrm{~b}$ & 17.0 & $\mathrm{~cd}$ \\
\hline 1-year-old wheat straw & $\operatorname{lx}$ & - & - & 2.3 & $\mathrm{~d}$ \\
\hline 1-year-old wheat straw & $2 \mathrm{x}$ & 一 & 一 & 0.7 & $\mathrm{~d}$ \\
\hline
\end{tabular}

${ }^{z} \mathrm{New}$ mulches refer to hay or wheat straw harvest in the same year as the trial, while old mulches refer to those harvested 1 year before the trial year.

yThickness indicates mulch rolled out between rows in one layer $(1 \mathrm{x})$ or two layers $(2 \mathrm{x})$.

${ }^{\mathrm{x}} \mathrm{lg}=0.0353 \mathrm{oz}$.

"Means within a column followed by the same letter are not significantly different according to Duncan's multiple range test at $P \leq 0.05$.

Table 3. Main effects means for dry weight of aboveground biomass for weeds per $16-\mathrm{ft}^{2}\left(1.5 \mathrm{~m}^{2}\right)$ plot of hay and wheat straw mulches used between rows of plastic in 2009 and 2010 in Lexington, KY.

\begin{tabular}{|c|c|}
\hline Treatment & $\begin{array}{c}\text { Weed dry wt } \\
(\mathrm{g})^{\mathrm{z}}\end{array}$ \\
\hline \multicolumn{2}{|l|}{ Mulch $^{y}$} \\
\hline Control (none) & $347.4 \mathrm{a}^{\mathrm{x}}$ \\
\hline New wheat straw & $40.0 \mathrm{~b}$ \\
\hline 1-year-old hay & $18.1 \mathrm{bc}$ \\
\hline New hay & $6.3 \mathrm{c}$ \\
\hline 1-year-old wheat straw ${ }^{\mathrm{w}}$ & $1.5 \mathrm{c}$ \\
\hline \multicolumn{2}{|l|}{ Thickness $^{\mathrm{v}}$} \\
\hline $1 \mathrm{X}$ & $29.5 \mathrm{a}$ \\
\hline $2 \mathrm{X}$ & $6.1 \mathrm{~b}$ \\
\hline \multicolumn{2}{|l|}{ Year } \\
\hline 2009 & $99.8 \mathrm{a}$ \\
\hline 2010 & $22.9 \mathrm{~b}$ \\
\hline \multicolumn{2}{|c|}{$\begin{array}{l}{ }^{2} 1 \mathrm{~g}=0.0353 \mathrm{oz} . \\
\text { "New mulches refer to hay or wheat straw harvest in } \\
\text { the same year as the trial, while } 1 \text {-year-old mulches } \\
\text { refer to those harvested l year before the trial year. } \\
\text { "Means within a column followed by the same letter } \\
\text { are not significantly different according to Duncan's } \\
\text { multiple range test at } P \leq 0.05 \text {. } \\
\text { w } 1 \text {-year-old wheat straw only was trialed in } 2010 \text {. } \\
\text { "Thickness indicates mulch rolled out between rows } \\
\text { in one layer }(1 \mathrm{x}) \text { or two layers }(2 \mathrm{x}) \text {. }\end{array}$} \\
\hline
\end{tabular}

of the mulch applied and were not oven-dried). Variability in the baling process that results in differences in the thickness of layers that peel off the bale as well as greater amounts of manual spreading required for the new straw mulches, also contributed to the variations in biomass mulch amounts. Because of the effect that differences in round bale source, age, type, and storage have on how bales unroll with the offset bale unroller, general statements regarding the number of round bales required per acre may not be appropriate.

WEED CONTROL WITH MULCHES. There was a significant mulch type by year interaction for the performance of the unrolled mulches for between-row weed control (Table 2). In both growing seasons, the nomulch control treatment had the greatest amount of weed biomass. In 2009, all mulch treatments had significantly less weeds than the no-mulch control, although were not significantly different from each other. In 2010, all of the mulch treatments except the 1-year-old hay placed in a single layer had significantly less weeds than the no-mulch control. Interestingly, the 1-year-old hay used in 2010 was part of the same lot of bales that was used as new hay in 2009. In 2009, the single layer of new hay did not have a weed biomass amount that was significantly different from the other mulch treatments. In 2010, single and double layers of 1-year-old wheat straw mulch and new hay and the double layer of 1-year-old hay had the least weed biomass present.

There were significant main effects for mulch type, thickness, and year for between-row weed biomass (Table 3). The no-mulch control had the highest level of weed biomass measured, followed by new wheat straw and 1-year-old hay. New hay and 1-year-old wheat straw mulches had the lowest levels of weed biomass. Much of the weed biomass present in the new wheat straw mulch was wheat grass, indicating that seeds present in the mulch contributed to weed pressure. Interestingly, after being stored for 1 year, the amount of weed biomass in the wheat straw mulch decreased, suggesting that the storage period may have been sufficient to reduce germination of wheat seed. This effect was not observed in the 1-yearold hay, particularly in 2010 , where the 1-year-old hay had significantly greater weed biomass than new hay (Table 2). The low weed biomass amounts for all of the other hay mulch treatments in both years suggest that weed seed was not being introduced with the particular source of hay that was being used in this study, thus the significantly higher weed biomass with the 1-year-old hay in 2010 may have been an anomaly of the particular hay bales used. There was not a significant mulch-type by thickness interaction. There was a significant main effect of mulch thickness on weed biomass (Table 3 ). Mulch applied in two layers had significantly less weed biomass present than mulch applied in a single layer. However, despite having more weeds, the single layer of mulch still appeared to provide adequate weed control, an important result as far as costs for the practice of mulching using round bales is considered. Year also had a significant effect on weed biomass measured, with 2009 having significantly greater weed biomass than 2010. In 2009, the rainfall amount during the growing season was 6 inches above normal, while it was slightly more than 5 inches below normal during the 2010 growing season. Thus, the wetter conditions may have resulted in greater weed pressure. In addition, in 2010, much of the rain that occurred was early in the season, allowing weed seeds to germinate and be cultivated before applying mulches followed by a prolonged dry period after mulches were applied.

\section{Conclusions}

These results suggest that hay and wheat straw mulches can be an effective weed control practice when used in conjunction with cultivation. Weed control with all of the mulches was significantly better than the control. The results also indicated that adequate weed control could be achieved with a single layer of mulch, reducing costs for mulching with 
round bales. The hay and wheat straw mulches were effective, even at application rates in the 15,000 to 20,000 $\mathrm{lb} /$ acre range.

Our results suggest that an offset bale unroller can make mulching of vegetable crops more efficient. The mulches trialed in this study are commonly available and relatively inexpensive in Kentucky. However, the offset bale unroller developed in this trial could likely be used with a wider variety of mulches that may be more commonly available in other regions of the United States. Leguminous mulches, which were not trialed in this experiment, may offer growers the ability to supply additional nitrogen to their production fields in a slow-release format. While this trial indicated that the offset bale unroller can effectively unroll mulches between rows, additional trials with a wider range of mulches could lead to more specific recommendations. The use of mulches is well-suited to the production of vining crops because it can provide continuing weed control after the vines fill in the space between rows, a time when essentially no other weed control measures (other than hand-pulling weeds) can be applied.

\section{Literature cited}

Coolong, T. 2012. Mulches for weed management in vegetable production, p. 57-74. In: A. Price (ed.). Weed control. Intech, Rijeka, Croatia.

Coolong, T., R. Bessin, K. Seebold, J. Strang, and S. Wright. 2011 . Vegetable production guide for commercial growers 2012-13. Univ. of Kentucky Coop. Ext. Serv. Bul. ID-36.

Diaz-Perez, J.C. 2010. Bell pepper (Capsicum annuum L.) grown on plastic film mulches: Effects on crop microenvironment, physiological attributes, and fruit yield. HortScience 45:1196-1204.

Lamont, Jr., W.J. 1993. Plastic mulches for the production of vegetable crops. Hort Technology 3:35-39.

Lamont, Jr., W.J. 2005. Plastics: Modifying the microclimate for the production of vegetable crops. HortTechnology 15:477-481.

Law, D.M., B. Rowell, J. Snyder, and M. Williams. 2006. Weed control efficacy of organic mulches in two organically managed bell pepper production systems. HortTechnology 16:225-232.

Ngouajio, M. and M.E. McGiffen. 2004. Sustainable vegetable production: Effects of cropping systems on weed and insect population dynamics. Acta Hort. 638:7783.

Plaskin, E. 2013. A simpler way to use round bales. Growing for Market 4(22): $8-9$.

Relf, D. and A. McDaniel. 2004. Mulches for the home vegetable garden. Virginia Coop. Ext. Publ. No. 426-326.
Rowe-Dutton, P. 1957. The mulching of vegetables. Commonwealth Bureau of Horticulture and Plantation Crops, Issue 24 of Technical Communication, Farnham Royal, UK.

Schonbeck, M. 1996. Mulching for weed control in annual vegetable crops. Virginia Assn. Biol. Farming. Info. Sheet No. 9.

Schonbeck, M. 2009. An organic weed control toolbox. 10 June 2013. <http:// www.extension.org/article/18532>.

Stall, W.M. 2008. Weed control in strawberry. Hort. Sci. Dept., Florida Coop. Ext. Serv., Inst. Food Agr. Sci., Univ. of Florida. HS 196.

Stout, R. 2011. Gardening without work: For the aging, the busy, and the indolent. Norton Creek Press. Blodgett, OR.

University of Kentucky. 2012. University of Kentucky Biosystems and Agricultural Engineering Department: Specialty crops mechanization plans. 10 June 2013. <http://jokko.bae.uky.edu/ext/Specialty_ Crops/plans.htm>.

Walz, E. 1999. Final results of the third biennial national organic farmers' survey. Organic Farming Res. Foundation. Santa Cruz, CA.

Zaniewicz-Bajkowska, A., J. Franczuk, and E. Kosterna. 2009. Direct and secondary effects of soil mulching with straw on fresh mass and number of weeds, vegetable yield. Pol. J. Environ. Stud. 18:1185-1190. 